\title{
"All This is Indeed Brahman" Rammohun Roy and a 'Global' History of the Rights-Bearing Self
}

\author{
Milinda BANERJEE \\ Presidency University \\ Kolkata, India \\ milindabanerjeeı@gmail.com
}

\section{Abstract}

This essay interrogates the category of the 'global' in the emerging domain of 'global intellectual history.' Through a case study of the Indian socialreligious reformer Rammohun Roy (1772/4-1833), I argue that notions of global selfhood and rights-consciousness (which have been preoccupying concerns of recent debates in intellectual history) have multiple conceptual and practical points of origin. Thus in early colonial India a person like Rammohun Roy could invoke centuries-old Indic terms of globality (vishva, jagat, sarva, sarvabhuta, etc.), selfhood (atman/brahman), and notions of right (adhikara) to liberation/salvation (mukti/moksha) as well as late precolonial discourses on 'worldly' rights consciousness (to life, property, religious toleration) and models of participatory governance present in an Indo-Islamic society, and hybridize these with Western-origin notions of rights and liberties. Thereby Rammohun could challenge the racial and confessional assumptions of colonial authority and produce a more deterritorialized and non-sectarian idea of selfhood and governance. However, Rammohun's comparativist world-historical notions excluded other models of selfhood and globality, such as those produced by devotional Vaishnava, Shaiva, and Shakta-Tantric discourses under the influence of nonBrahmanical communities and women. Rammohun's puritan condemnation of non-Brahmanical sexual and gender relations created a homogenized and hierarchical model of globality, obscuring alternate subaltern-inflected notions of selfhood. Class, caste, and gender biases rendered Rammohun sup- 
portive of British colonial rule and distanced him from popular anti-colonial revolts and social mobility movements in India. This article argues that today's intellectual historians run the risk of repeating Rammohun's biases (or those of Hegel's Weltgeschichte) if they privilege the historicity and value of certain models of global selfhood and rights-consciousness (such as those derived from a constructed notion of the 'West' or from constructed notions of various 'elite' classicized 'cultures'), to the exclusion of models produced by disenfranchised actors across the world. Instead of operating through hierarchical assumptions about local/global polarity, intellectual historians should remain sensitive to and learn from the universalizable models of selfhood, rights, and justice produced by actors in different spatio-temporal locations and intersections.

\section{Key words}

global intellectual history, Rammohun Roy, selfhood, history of rights, colonialism, hybridity

\section{INTRODUCTION}

There has been in recent years a marked 'global' turn in historical studies, and the domain of intellectual history has been no exception to this trend. The publication in 2013 of the volume Global Intellectual History, edited by Samuel Moyn and Andrew Sartori, can be seen as an ambitious attempt to conceptualize and debate the manner in which the category of the 'global' can introduce new themes of discussion and new tools of analysis into the study of intellectual history. ${ }^{1}$ Taking the debates unleashed by this volume as my point of departure, I suggest that the emerging field of 'global intellectual history' is ultimately embedded in contested assumptions about the 'globality' of historical structures and actors. A critical overview of such assumptions is, needless to say, necessary. The aim of this essay is to partially address this problem by focusing on a specific historical actor, the Indian (Bengali) reformer Rammohun Roy (1772/41833), often described (however inaccurately) as the 'father of modern India' for his pioneering role in introducing new forms

${ }^{1}$ Samuel Moyn and Andrew Sartori, eds., Global Intellectual History (New York: Columbia University Press, 2013). 
of religious transformation, social activism, and constitutionalist politics in early nineteenth century India, and furthermore for linking these Indian agitations to global campaigns for socialpolitical reform through his activist career in Britain, and through the dissemination of his writings already in his lifetime through Europe and North America. I suggest that Rammohun constructed a vision of a 'global' self by creating relationships between multiple Sanskritic, Perso-Islamic, and European models of globality, and thereby also offering a kind of world-historical approach based on comparisons between the cultural mores of different societies. A study of Rammohun Roy can lay bare the diverse genealogies of a supposedly 'universal' self, a self which was furthermore constructed as a rights-bearing self. The example of Rammohun demonstrates some of the metaphysical subtexts that can underlie 'global' positions. A close look at his writings helps us examine the porous frontiers between the 'universalistic,' 'the world-historical,' and the 'global' approaches to historicity and thus exposes the malleable nature of the borders between these categories. One can thereby confront the ideological underpinnings of historical visions and problematize the category of the 'global' as already inflected by latent universalistic assumptions which need to be confessed rather than simply wished away. Finally, given that the origins, character, and nature of the rights-bearing self have been preoccupying concerns of recent interventions in intellectual history, a study of Rammohun as a world historian and as simultaneously a subject of global intellectual historical critique can expose the multiple roots of such a self and the problems inherent in too reductive a construction of globality or, for that matter, of global intellectual history.

\section{INTELLECTUAL HiSTORIES AND ANXIETIES ABOUT THE 'GLOBAL'}

The choice of Rammohun Roy for examining methodologies of 'global intellectual history' is not fortuitous. Andrew Sartori's 
first monograph, Bengal in Global Concept History: Culturalism in the Age of Capital (2008) took Rammohun as the initial point of departure to suggest that global movements in capital and the global spread of capitalist mode of production, as inaugurated at least from the early nineteenth century, aided in the construction of a global self; Rammohun's model of the pious householder was an instantiation of this nexus. According to Sartori, some decades later, as the colonial nature of capitalism and racial divides demonstrated the impossibility of global ideological unity, anti-colonial nationalist elites in Bengal turned away from Rammohun's vision towards more territorialized understandings of national identity. ${ }^{2}$ This focus on the interfaces of 'concept' and 'capital' is visible in another of Sartori's essays where he analyzed the fascination for 'Germany' in colonial Bengali imagination. Abjuring simplistic explanations about inter-civilizational conversation or East-West binary, he offered nuanced models of ideational convergence which were produced through parallels and convergences in changing political economies of different globally-connected regions. ${ }^{3}$ This methodology is continued in his essay in the 2013 volume which pursues the interrogation of the ambivalent nexus between capitalism and the 'global.'

Sartori's intervention can be situated within a broader anxiety in South Asian studies to grapple with the 'global' in history and historiography. Christopher Bayly has been a pioneer in relating South Asian history to studies of the wider world; along with Sanjay Subrahmanyam, he is one of the most successful South Asianists to have also become pioneer practitioners of global history. ${ }^{5}$ Common to both Bayly and Subrahmanyam is an appreciation for the longue durée: rather than seeing Europe as the sole progenitor of modernity, both, in their differing ways, underline the complex and diverse socio-economic, cultural-

${ }^{2}$ Andrew Sartori, Bengal in Global Concept History: Culturalism in the Age of Capital (Chicago: Chicago University Press, 2008).

${ }^{3}$ Andrew Sartori, "Beyond Culture-Contact and Colonial Discourse: 'Germanism' in Colonial Bengal,” Modern Intellectual History 4, no. 1 (April 2007): 77-93.

${ }^{4}$ Andrew Sartori, "Global Intellectual History and the History of Political Economy," in Global Intellectual History, ed. Moyn and Sartori, 110-33.

${ }^{5}$ Among Bayly's global-historical interventions are C. A. Bayly, Imperial Meridian: The British Empire and the World, 1780-1830 (Harlow: Pearson, 1989) and Bayly, The Birth of the Modern World, 1780-1914 (Oxford: Blackwell, 2003). 
religious, and political forms which have been present in different societies of the world and which have together contributed through complicity, convergence, and contestation to the emergence of global 'modernities.' Almost singlehandedly, Subrahmanyam has made the category of 'early modernity' an academically respectable way of understanding late precolonial histories of Asia (perhaps especially South Asia). ${ }^{6}$ On his part, Bayly has underscored how extra-European actors have hybridized moralpolitical categories derived from their own contexts with European ones to carve out innovative worlds. Rather than seeing Europe as an all-embracing all-explaining prime cause of historical change, Bayly has consistently emphasized the relevance of studying local diversities. His volume Recovering Liberties: Indian Thought in the Age of Liberalism and Empire (2012) is archetypal of this approach. ${ }^{7}$ Rammohun plays an important part in this volume as someone who mingled Perso-Islamic and Indic ethical-political repertoires with European ones to carve out his social reformist grammar. Bayly's first major contribution to Rammohun studies was published in a special issue of the journal Modern Intellectual History in $2007 ;^{8}$ like the other contributors to that issue, later published as a volume An Intellectual History for India (2010) edited by Shruti Kapila, ${ }^{9}$ Bayly wished to embed Indian intellectual history "in a wider Asian, European and American context, further developing the notion of a global or trans-national sphere of intellectual history." ${ }^{10}$ Sartori and Bayly offer parallel as well as complementary ways of doing

${ }^{6}$ From Subrahmanyam's oeuvre, particular mention may be made of Sanjay Subrahmanyam, "Connected Histories: Notes Towards a Reconfiguration of Early Modern Eurasia," Modern Asian Studies 31, no. 3 (July 1997): 735-62; Sanjay Subrahmanyam, From the Tagus to the Ganges: Explorations in Connected History (Delhi: Oxford University Press, 2012); Sanjay Subrahmanyam, Courtly Encounters: Translating Courtliness and Violence in Early Modern Eurasia (Cambridge, Mass.: Harvard University Press, 2012).

${ }^{7}$ C. A. Bayly, Recovering Liberties: Indian Thought in the Age of Liberalism and Empire (Cambridge: Cambridge University Press, 2011).

${ }^{8}$ C. A. Bayly, "Rammohan Roy and the Advent of Constitutional Liberalism in India, 1800-30,” Modern Intellectual History 4, no. 1 (April 2007): 25-41.

${ }^{9}$ Shruti Kapila, ed., An Intellectual History for India (Cambridge: Cambridge University Press, 2010).

${ }^{10}$ Bayly, "Rammohan Roy,” 25. 
global intellectual history with Rammohun constituting a formative exemplar for both in terms of articulating their methodologies. Both differ from a third way of seeing Rammohun which casts him as the heir of an unchanging but updateable Indian sacred tradition, a view once offered by the famous poet Rabindranath Tagore, " and which often continues to be expressed in public-political discourse.

To return to the volume Global Intellectual History edited by Moyn and Sartori, the different historians who have contributed to the volume have not arrived at any consensus about what makes for globality and therefore what constitutes the main parameters of a global intellectual history. With only two articles (by Siep Stuurman and Sheldon Pollock) on the preeighteenth century world, ${ }^{12}$ the volume does establish an elective affinity between the 'global' and the 'modern.' Such an equation perforce gives Europeans a certain primacy in constructing the 'global,' as if no globality could really exist before the age of empire. The contributors of the volume tackle this problem headon. As Samuel Moyn suggests, the contribution of non-European actors in global history frequently becomes reduced to that of accepting and extending a universalism which is first created by the Europeans themselves, even if (due to the exigencies of colonialism) Europeans cannot themselves practically instantiate their universalistic ideals. This problem of a historiographic model of 'truncated universalism' - where Europeans create a universalistic selfhood but fail to realize this in practice, while non-Europeans, especially through anti-colonial movements, instantiate the universalism-is also discussed by Sudipta Kaviraj in the final chapter. ${ }^{13}$ Meanwhile other scholars, including Cemil Aydin (on the Islamic world), Mamadou Diouf and Jinny Prais (on Africa), and Janaki Bakhle (on India) also express their dissatisfaction with the equation of the global with the Euro-

${ }^{11}$ See the speeches delivered between 1885 and 1941. Rabindranath Tagore, Ravindrarachanavali (Calcutta: Government of West Bengal, 1989), 11:191-98, 219-46.

${ }^{12}$ Siep Stuurman, "Common Humanity and Cultural Difference on the SedentaryNomadic Frontier: Herodotus, Sima Qian, and Ibn Khaldun,” in Global Intellectual History, ed. Moyn and Sartori, 33-58; Sheldon Pollock, "Cosmopolitanism, Vernacularism, and Premodernity," in ibid., 59-80.

${ }^{13}$ Samuel Moyn, "On the Nonglobalization of Ideas," in ibid., 187-204; Sudipta Kaviraj, “Global Intellectual History: Meanings and Methods,” in ibid., 295-319. 
American. ${ }^{14}$ Frederick Cooper, a celebrated historian of Africa, is perhaps the most radical in critiquing the Eurocentric assumptions behind the category of the 'global' in global intellectual history. ${ }^{15}$ But the volume does not offer any consensual model of how this critique can be addressed. Neilesh Bose's recent review of the volume (2014) therefore articulates a sense of despair about whether the 'global' can at all satisfactorily address the complexities of diversity in intellectual-social responses in different localities of the world. He asks: 'Does the framing of intellectual history in "global" terms . . . obscure, potentially, histories that resist being slotted into a "global" categorization?"16

Within this fraught world of dispute on global intellectual history, the present essay offers some exploratory suggestions through an analysis of Rammohun's concept of a 'global' rightsbearing self. My focus on this selfhood is not coincidental. Practitioners of intellectual history have frequently stressed the role of concepts of rights-consciousness in globalizing liberaldemocratic values and political assumptions about collective and individual autonomy. Recent examples of such approaches include David Armitage's The Declaration of Independence: A Global History (2007) ${ }^{17}$ and Samuel Moyn's history of the idea of human rights, The Last Utopia: Human Rights in History (2012). ${ }^{18}$ In spite of these pioneering interventions, there is as yet no consensus about what role non-European actors have played in producing 'global' ideas of rights-consciousness. The model of 'truncated universalism,' as already noted above, has been widely dis-

${ }^{14}$ Cemil Aydin, "Globalizing the Intellectual History of the Idea of the 'Muslim World,"” in ibid., 159-86; Mamadou Diouf and Jinny Prais, “'Casting the Badge of Inferiority Beneath Black Peoples' Feet': Archiving and Reading the African Past, Present, and Future in World History," in ibid., 205-27; Janaki Bakhle, "Putting Global Intellectual History in its Place,” in ibid., 228-53.

${ }^{15}$ Frederick Cooper, "How Global Do We Want Our Intellectual History to Be?” in ibid., 283-94.

${ }^{16}$ Neilesh Bose, "Hiding the Nation in the Global: Modern Intellectual History and South Asia,” Journal of Colonialism and Colonial History 15, no. 2 (Summer 2014).

${ }^{17}$ David Armitage, The Declaration of Independence: A Global History (Cambridge, Mass.: Harvard University Press, 2007).

${ }^{18}$ Samuel Moyn, The Last Utopia: Human Rights in History (Cambridge, Mass.: Harvard University Press, 2010). 
cussed and found unsatisfactory, though no alternative has perhaps yet been offered to replace it. The present essay hopes to offer a new way of looking at the 'globality' of global intellectual history through an examination of the putative globality and multi-centered genealogies of the rights-bearing self in Rammohun Roy and South Asia. The title of this article contains an allusion to Charles Taylor's magnum opus Sources of the Self: The Making of the Modern Identity (1989); ${ }^{19}$ this allusion constitutes both an act of homage (in that many of my concerns about the ethical presuppositions of selfhood match Taylor's) as well as an act of critique (given Taylor's exclusionary focus on Europe and Christianity in narrating the origins of the modern self, thereby marginalizing extra-European contributions).

\section{THE UNIVERSAL SELF AND THE RIGHT (ADHIKARA) TO SALVATION}

If we are to write a 'global' history of the self as instantiated through Rammohun, then first and foremost we have to reckon with his soteriology. I would argue that for Rammohun the final determinate of equality and globality was the idea of the self. In his Sanskrit and Bengali writings, Rammohun uses the millennia-old Indic term atman, translating this as 'soul' in his English writings. Rammohun identified this atman with brahman, imprecisely and in a sense inaccurately translated by him as 'God' using a borrowed Christian vocabulary. The title of my essay derives from a line in the Chhandogya Upanishad, part of the Vedic corpus and probably composed sometime in the first millennium BCE. In his Vedantagrantha (1815), Rammohun quoted the line in the Sanskrit original: sarvam khalvidam brahman. ${ }^{20}$ In the

${ }^{19}$ Charles Taylor, Sources of the Self: The Making of the Modern Identity (Cambridge, Mass.: Harvard University Press, 1989).

${ }^{20}$ Rammohun Roy, "Vedantagrantha," in Ramamohana Rachanavali (Calcutta: Haraf, 1973), 12. The authorship of some of Rammohun's works have been disputed; unless stated otherwise, I have followed this edition of the rachanavali and the edition of the English works given in the next footnote in attributing authorship. The exact authorship of the works is not of great importance to the argument of this essay; if some treatise traditionally attributed to Rammohun in fact was written by someone else among his colleagues and followers, it does not take away from our argument about the multiple origins of ideas of the global and rights-bearing self in Rammohun and his milieu. 
English version of this treatise (1816), he rendered this line as "All that exists is indeed God." Rammohun's understanding of globality was embedded in frequent use of terms such as vishva, jagat, and sarva in Sanskrit and Bengali quotations and writings, and the use of terms such as "universe," "world," and "all" in English works.

Rammohun did not develop his perspectives on globality out of a vacuum. The first of his works which has survived is in fact a Persian treatise with an Arabic introduction, the Tuhfat-ulMuwahhidin (1803-4), a clear product of the Perso-Islamic debating spheres of Mughal India. In this treatise Rammohun adopted a kind of comparative-historicist approach suggesting that through his travels through plains and hilly lands he had discovered that people of different sects differed in their understanding of religiosity. Given their propensity to contradict each other while always upholding their own dogmas as final truth, it was obvious (Rammohun suggested) that falsehood was common to all religions. The true essence of religion was morality which enjoined people to refrain from harming each other and respect each other's property rights. Rammohun sought to expose all other beliefs, whether present in Indic or Islamic ideologies, such as beliefs in the superiority of one's own faith or in miracles, as false and non-essential. Simultaneously, through quotations from the fourteenth century Iranian Sufi poet Hafez and references to Perso-Islamic hermeneutics, Rammohun drew on Islamic monotheism to articulate his worldview. ${ }^{22}$ Such a comparativist perspective had predecessors in Mughal India, for example, in the debates carried out in the late sixteenth century court of the Mughal Emperor Akbar, in the seventeenth century under the auspices of Akbar's great-grandson Dara Shikoh, and in the seventeenth century treatise Dabistan-i Mazahib. ${ }^{23}$ In

${ }^{21}$ Rammohun Roy, "Translation of an Abridgment of the Vedant," in The English Works of Raja Rammohun Roy (Allahabad: The Panini Office, 1906), 10.

${ }^{22}$ Rammohun Roy, "A Present to the Believers in One God, Being a Translation of Tuhfatul Muwahhiddin,” in The English Works, 941-58.

${ }^{23}$ M. Athar Ali, "Pursuing an Elusive Seeker of Universal Truth: the Identity and Environment of the Author of the Dabistan-i Mazahib," Journal of the Royal Asiatic Society of 
Bengal, Bharatachandra's celebrated work Annadamangal (1752), composed under the patronage of a local Hindu ruler Krishnachandra, also offered a comparativist framework which, I would argue, bears similarities with Rammohun's vision: the author compared Islam with what he described as 'Hindu' belief to suggest that they shared a common belief in one divinity (ishvara). Present in Bharatachandra was an incipiently global vision based on the equivalence of different faiths and categories of beings to denounce the possibility of one sect having a monopoly over true belief and therefore being better than others: "Hindus, Muslims, and whatever animals and living creatures there are, they all have one divinity . .."24 This presence of Islam in provoking globality contradicts Bruce Robertson's assertion that the Tuhfat was an unimportant treatise and that Rammohun only represented the regeneration of a Vedic worldview. ${ }^{25}$

Sanjay Subrahmanyam has suggested that there were already 'world historians' in the sixteenth century, not merely in Europe, but also in the Ottoman or Mughal Empires. ${ }^{26}$ I would suggest that Rammohun's perspective stands at the cusp of an early modern genealogy of 'world history' and a more specifically European-inflected colonial-modern one. His comparativist polemical position in the Tuhfat owed something to his extensive travels through northern India, Bhutan, and arguably Tibet. The traces of precolonial inheritances differentiate Rammohun from someone like Hegel; unlike Hegel's Weltgeschichte which firmly announced the superiority of the European over the nonEuropean, ${ }^{27}$ Rammohun's globally-embedded historicity brought different societies on a plane of equivalence based on their

Great Britain and Ireland 9, no. 3 (1999): 365-73; Syed Ali Nadeem Rezavi, "Religious Disputations and Imperial Ideology: The Purpose and Location of Akbar's Ibadatkhana," Studies in History 24, no. 2 (2008): 195-209; Jonardon Ganeri, "Dara Shukoh and the Transmission of the Upanisads to Islam," in Migrating Texts and Traditions, ed. W. Sweet (Ottawa: University of Ottowa Press, 2009), 150-61; Audrey Truschke, "Cosmopolitan Encounters: Sanskrit and Persian at the Mughal Court” (PhD diss., Columbia University, 2012).

${ }^{24}$ Bharatachandra, "Annadamangal," in Ramaprasada Bharatachandra Rachanasamagra (Calcutta : Reflect Publication, 2004), 335.

${ }^{25}$ Bruce Carlisle Robertson, Raja Rammohan Roy: The Father of Modern India (Delhi: Oxford University Press, 1995), 24-30.

${ }^{26}$ Sanjay Subrahmanyam, "On World Historians in the Sixteenth Century,” Representations 91, no. 1 (2005): 26-57.

${ }^{27}$ For a critical account of Hegel's Weltgeschichte, see Ranajit Guha, History at the Limit of World-History (New York: Columbia University Press, 2003). 
commonalities in belief in divinity and differences in nonessential matters such as the proclamation of sectarian supremacy. Whereas the path of progress has a Europe-oriented unilinear direction for Hegel's world-history, for Rammohun, different individuals are situated in history and society but there exists no linear movement of progress which places some races on a higher plane than others. The European-Christian (phiringi, from Frank) had been still only a marginal presence in Bharatachandra, ${ }^{28}$ but the onset of British rule ensured that it would become a far more important presence in Rammohun's scheme of comparativist world history. But, nonetheless, significant elements in his hermeneutic scheme undoubtedly predated colonial capitalism.

Rammohun's comparativist schema also owed a lot to Sanskritic worlds of debate, especially the forms of bhashya (commentary) and vichara and samvada (disputation) through which Rammohun argued against his Indian opponents. ${ }^{29}$ The style (as opposed to the contents) of Rammohun's disputations has received little attention till now. I would argue that it is the style and format of disputation which allowed an enunciation of the global and the historical in Rammohun. To defeat his opponents, Rammohun had to continually universalize his arguments; the form of tarka (logical disputation) and yukti (reasoning) propelled him to resort to arguments rather than dogma or mystical faith to champion his beliefs..$^{30}$ Rammohun quoted, for example, the seer Brhaspati: kevalam shastramashritya na kartavyo vinirnayah, yuktihinavicharena dharmahanih prajayate-to sug-

${ }^{28}$ Bharatachandra, “Annadamangal,” 336.
${ }^{29}$ See Roy, Ramamohana Rachanavali, for these commentaries and debates.
${ }^{30}$ Roy asserted the importance of Veda-embedded tarka and yukti: see Roy, "Vedantagrantha," 21, and "Gosvamir sahita Vichara," in Ramamohana, 163-64. See also Milinda Banerjee, Rammohun Roy: A Pilgrim's Progress, Intellectual Strands and Premises in Rammohun Roy's Pursuit of Reason, God, and Common Sense in Early Modern India (Calcutta: Centre for Archaeological Studies and Training, 2009); Milinda Banerjee, "Doubt, Authority, and the Individual. Rammohun Roy, Christian Missionary Discourses and Political Theology in Early Nineteenth-Century Bengal,” in Individualisierung durch christliche Mission? [Individualization through Christian Missionary Activity?] ed. Martin Fuchs, Antje Linkenbach-Fuchs, and Wolfgang Reinhard (Wiesbaden: Harrassowitz, 2015), 438-56. 
gest that knowledge could not be gathered from shastra (roughly, sacred texts) alone, since dharma (morality) was endangered when shastras were used without using tarka. ${ }^{31}$ Rammohun stressed on vichara which was embedded (as Brhaspati and others had noted) in yukti and tarka.

To assert his 'global' vision, the Advaita (non-dualistic) interpretation of philosophy (and especially of the Vedanta) came in handy. Rejecting recent arguments that the Vedanta became hegemonic only in the colonial period as a basis of constructing Hindu nationalism, Andrew Nicholson has suggested that at least from the twelfth century there had been a tendency towards creating a unified understanding of Hinduism. ${ }^{32}$ In Rammohun's case, Advaita proved useful for constructing the vision of a unified world. Rammohun rejected Samkhya and Vaisheshika philosophies of precolonial India because they differentiated between the individual atman, the divine self, and the material world. ${ }^{33}$ Instead Rammohun extensively quoted Vedic texts (especially the Upanishads), using Advaita exegesis, to suggest that the atman and the brahman were one, and that brahman was pervaded throughout the world and through all. To take just two instances, in the Vedantagrantha he says brahma sarvavyapi (brahman is pervaded through all), ${ }^{34}$ and in an 1818 treatise explaining the meaning of the Gayatri Mantra, he says samuday jagat parabrahmamaya hayen (all the world is filled with the supreme brahman). ${ }^{35}$

The next question was as to whether everyone could equally access brahman and thereby gain salvation. There was no consensus in precolonial India about this; advocates of a strict varna-jati and gender stratification scheme denied the possibility of this, while others suggested that it was indeed possible for all, irrespective of birth and status, to achieve divinity. In a sense, in

${ }^{31}$ Roy, "Gosvamir Sahita Vichora,” in Ramamohana, 163-64.

${ }^{32}$ Andrew J. Nicholson, Unifying Hinduism: Philosophy and Identity in Indian Intellectual History (New York: Columbia University Press, 2000).

${ }^{33}$ Roy, "Vedantagrantha," in Ramamohana, 20-22. Cf. Shankaracharya, Brahmasutrabhashya, 2.2.1 and 2.2.2. For translating this bhashya, I use throughout this essay. Shankaracharya, Brahma-Sutra-Bhasya, trans. Swami Gambhirananda (Calcutta: Advaita Ashrama, 2009).

\footnotetext{
34 Ibid., 8.

${ }^{35}$ Roy, “Gayatrir Artha,” in Ramamohana, 178.
} 
the Sanskritic world, this was the most important test case about whether all human beings had a certain equivalent status, or whether there was a radical difference between different categories of beings. Extensively quoting Shankaracharya (eighth century?) and especially his commentary on the Brahmasutra or the Brahmasutrabhashya, Rammohun argued that the Shudra scholar-courtier Vidura, the butcher Dharmavyadha, and even those outside the varna order, such as Raikva and the naked Samvarta, or women, like Gargi Vachaknavi, could achieve liberation. Citing the Brahmasutrabhashya, Rammohun argued that liberation was possible not only through knowledge of the Vedic texts (formally denied to Shudras and women), but also through other sorts of texts such as purana, itihasa, and agama, to which everyone had access. Rammohun also cited examples of women mentioned in the Vedic corpus such as Brahmavadini and Maitreyi, and Sulabha, mentioned in smriti and bhashya literature, to show the capacity of all to attain liberation through knowledge of brahman. ${ }^{36}$ While Shankaracharya's complex enunciations about the significance of varna are capable of multiple deployments, Rammohun obviously interpreted the bhashya in a way that favored his own position. Furthermore, quoting the Gita, Rammohun noted how liberation had been promised to anyone, no matter of what status, and even if they left their position within the varna and ashrama (life-stage) order, as long as they worshipped the divine one. ${ }^{37}$ On the question of whether householders could achieve knowledge of brahman, Rammohun invoked the examples of the king Janaka, the prince Arjuna, and others engaged in worldly (laukika) activities such as Vashishtha, Parashara, Sanatkumara, and Vyasa. He also quoted the seer Manu and his later commentator Kulluka Bhatta to argue that

${ }^{36}$ Shankaracharya, Brahmasutrabhashya, 1.3.34-38 and 3.4.35-38; Rammohun Roy, "Vedantagrantha," 51, "Vedantasara” (1815), 68, "Bhattacharyer sahita Vichara” (1817), 114, "Mandukyopanishat" (1817), 144, "Mundakopanishat” (1819), 184, "Subrahmanya Shastrir sahita Vichara” (1820), 229-31, "Pathya Pradana” (1823), 279, 284-85, in Ramamohana.

37 Roy, "Mandukyopanishat” (1817), 144, "Subrahmanya Shastrir sahita Vichara” (1820), 229-231, "Pathya Pradana” (1823), 279, 289. 
householders could pursue the knowledge and worship of atman. ${ }^{38}$ In 1827, Rammohun translated into Bengali the Vajrasuchi, a text of uncertain origin, to suggest that it was not birth, but knowledge of brahman and gentle, generous, and pious conduct that made a person a Brahmin. Thus seers of ancient times had achieved Brahmin status even when born from low-status human mothers, animals, or inanimate objects. ${ }^{39}$ Similar meditations on the identity of the true Brahmin can also, incidentally, be found in Shankaracharya (where a kind-hearted person is considered a Brahmin irrespective of anything else). ${ }^{40}$

There was thus a centuries-old resource in Sanskritic ideas which allowed Rammohun, through intertextual quotation, to re-affirm all human beings (including those low in the varna hierarchy, those altogether outside it, or women) to be equivalent, as being alike manifestations of the divine brahman, and alike endowed with the right (in Sanskrit and Bengali texts of Rammohun, adhikara) to achieve liberation or salvation. ${ }^{41}$ There was, in this ultimate instance, no ultimate difference between beings. No one, solely on account of their birth or vocation in life, could be denied this final equivalence with divinity. It was this which made Rammohun's self 'global,' at least in epistemological orientation. Rammohun's use of Sanskrit texts to advance soteriological arguments about the globally-pervaded self was thus not a simple product of the age of empire and European Orientalism: it stemmed from pre-existing Advaita and devotional-Bhakti forms of exegesis, and was directed against upholders of varna rigidities as well as against Samkhya and Vaisheshika discourses.

Rammohun had various other devotional traditions also in mind in articulating his vision of the 'global' self. Across the first and second millennia CE, different devotional movements had

${ }^{38}$ Roy, “Ishopanishat” (1816), 76, 78, “Chari Prashner Uttara” (1822), 252, “Mandukyopanishat” (1817), 147-48, "Pathya Pradana” (1823), 279, 284-85, "Brahmanishtha Grihasther Lakshana" (1826), 331-32, in Ramamohana.

${ }^{39}$ Roy, "Vajrasuchi," in Ramamohana, 334-37.

${ }^{40}$ Shankaracharya, Brahmasutrabhashya, 3.4.38.

${ }^{41}$ On Roy's use of the term adhikara, see for example "Subrahmanya Shastrir sahita Vichara" (1820), 229-31, in Ramamohana; this Sanskrit vichara with a southern Indian Brahmin gives one of the most detailed expositions on adhikara of all human beings to knowledge of brahman (brahmavidya) and to liberation. Rammohun adopts this vocabulary of adhikara from Shankaracharya (Brahmasutrabhashya, 1.3.38). 
arisen in different parts of India which promised salvation to people if they became devoted to divinity and behaved righteously. In northern India such movements had erupted with particular strength between the fifteenth and eighteenth centuries, acquiring large following among those low in the varna order, such as peasant and artisanal-mercantile communities and women. ${ }^{42}$ Rammohun cited these Bhakti (devotion)-oriented sant movements, and especially those associated with Nanak, Kabir, Dadu, and the Shivanarayana tradition. ${ }^{43}$ The Bhagavata Purana (which dated to the first millennium but had gained widespread appeal in the second millennium through the devotional movements) was quoted by Rammohun to suggest that divinity was present in all beings (sarveshu bhuteshu) and throughout the world (sacharacharam). ${ }^{44}$ Rammohun's worldhistorical vision can be seen also in the way in which he invoked Islam and Christianity to suggest that people in different corners of the world worshipped a unitary divinity; it was thus not true, as some of Rammohun's Indian opponents suggested, that ordinary human beings could only understand the worship of a multiplicity of gods. ${ }^{45}$

Sheldon Pollock has suggested that a certain temporal consciousness differentiating between older and newer discourses (prachina, prachinanuyayin, navina, atinavina, adhunika) had already emerged in the Sanskritic world in the late precolonial period. ${ }^{46}$ In Bengal, in a text of early seventeenth century origin

${ }^{42}$ The academic literature on these movements is too vast to be summarized here. For some recent historiographic summaries and interventions, see Rameshwar Prasad Bahuguna, "Beyond Theological Differences: Sant-Vaishnava Interaction in Medieval India," Indian Historical Review 36, no. 1 (2009): 55-79; Christian Lee Novetzke, Religion and Public Memory: A Cultural History of Saint Namdev in India (New York: Columbia University Press, 2011).

${ }^{43}$ Roy, "Vedantagrantha,” 8, "Prarthanapatra” (1823), 260-61, in Ramamohana; Roy, "A Defence of Hindoo Theism in Reply to the Attack of an Advocate for Idolatry at Madras" (1817), 96, and "Humble Suggestions to His Countrymen who Believe in the One True God" (1823), 211, in English Works.

${ }^{44}$ Roy, "Gosvamir sahita Vichara,” in Ramamohana1, 66-67.

${ }^{45}$ See the references given in footnote 43.

${ }^{46}$ Sheldon Pollock, "New Intellectuals in Seventeenth-Century India," The Indian Economic and Social History Review 38, no. 1 (2001): 3-31. 
such as Chaitanyacharitamrita, we find differences being constructed between older and more recent (adhunika) texts; in Chaitanyacharitamrita, this valuation occurs in a public debate between Chaitanya (1486-1534) and an Islamic qazi (judge) in a context of widespread public agitation against the latter's efforts to prevent Chaitanya-led devotional-social activities. ${ }^{47}$ The temporality of Rammohun's consciousness demonstrated a sustained engagement with history: belief in unitary divinity, rather than a multiplicity of gods, was warranted because such a belief was present in the most ancient and uncorrupted of Indian texts as well as in other parts of the world. Such a historicized temporal consciousness had roots in Western-modern ideas of historicity and ideas of Protestant-Christian reformation, ${ }^{48}$ but it also had older lineages. And finally, the very idea of a universal self had moorings in ancient (and in late precolonial and early colonial India, still widely known) philosophical worldviews, as well as in devotional movements that had arisen amongst gentrifying peasant-pastoralist and artisanal-mercantile groups benefiting, already since the precolonial period, from transregional channels of economic growth and commercialization.

IV. Rights OF the SelF: Life, Property, Religious AND Civil LiBERTIES, AND PARTICIPATION IN GOVERNMENT

The 'globality' of Rammohun's self had firm roots in notions of salvation, but it also had this-worldly implications. In fact, it would be inappropriate to think of too rigid a separation between the right to salvation and other more material rights. Rammohun's most celebrated campaign, to abolish the practice of sati or widow immolation, shows these connections: because women had the right to salvation (moksha), he argued, therefore

${ }^{47}$ Krishnadasa, Shrishrichaitanyacharitamrita (Calcutta: Ananda Publishers, 1995), 103.

${ }^{48}$ Roy saw Luther as a positive exemplar of a reformer who saved Christianity by attempting to restore it to its original pure state, freed from the degradation caused in later centuries. See Letter to Dr. T. Rees of London, 4 June 1824, and Letter to William Ward of Medford, 5 February, 1824, in Ramamohana, 453, 473. See also his confession to the Scottish missionary Alexander Duff, recorded in George Smith, The Life of Alexander Duff. vol. 1 (New York: A. C. Armstrong and Son, 1879), 118. 
even after their husbands had died, they should be able to live so that they could try to achieve liberation (mukti). While widowimmolation was theoretically voluntary, in practice it was often coercively imposed in precolonial and early colonial India, so that male members of the family could remove the widow from property inheritance and simultaneously claim higher social status through their association with a woman who had been pious enough to commit sati. Rammohun's successful campaign to ban the practice had both soteriological and material justification: the woman had to be allowed to live for her moral future as well as out of reasons of humane consideration. The campaign also showed Rammohun's use of historicity; ancient (prachina) seers (such as Manu and Yajnavalkya) were invoked as against supposedly later or recent (adhunika) texts to argue about the evil nature of customs which had arisen from social degeneration. ${ }^{49}$

While there were precolonial precedents (for example, the efforts by the Mughal Emperors Akbar and Jahangir and the Maratha Peshwa Baji Rao) to abolish or discourage sati,,$^{50}$ the success of Rammohun's campaign was undoubtedly the product of British governmental support for this reform project. However, of the other issues which were part of Rammohun's 'civil society' activism, many had hybrid roots: they were rooted in idioms of rights-consciousness present in precolonial South Asia, and were simultaneously also articulated through European-origin liberalhumanitarian models and British-sanctioned legality. This hybridity of rights-discussions has not received sufficient attention till now with respect to their precolonial Indian roots; even the magisterial survey of Dilipkumar Biswas, which pays the most

49 Roy, "Sahamarana Vishaye Pravartaka o Nivartaker Samvada” (1818), 169-75, "Sahamarana Vishaye Pravartaka o Nivartaker Dvitiya Samvada” (1819), 189-203, "Sahamarana Vishaya” (1829), 358-62, in Ramamohana; Roy, "Translation of a Conference Between an Advocate for, and an Opponent of, the practice of Burning Widows Alive” (1818), "A Second Conference Between an Advocate for, and an Opponent of, the practice of Burning Widows Alive” (1820), "Abstract of the Arguments regarding the Burning of Widows, considered as a Religious Rite” (1830), in English Works, 321-72.

${ }^{50}$ R. C. Majumdar, "Sati," in The History and Culture of the Indian People: British Paramountcy and Indian Renaissance, ed. R. C. Majumdar (Bombay: Bharatiya Vidya Bhavan, 1991), 2:268. 
detailed attention to Rammohun's conversations with precolonial discourses, neglects the precolonial discussions on rights from which Rammohun drew his lineage. ${ }^{51}$ Property 'rights' were, in a sense, the crucial lynchpin of Rammohun's activism; he wanted to ensure property rights for individuals (such that individuals could alienate property to whoever they liked, irrespective of lineage constraints) ${ }^{52}$ and adequate property inheritance rights for women. ${ }^{53}$ Of course, much before Rammohun, there had been debates on the relation between property and social hierarchy and state power in Bengali language discourses. The Chandimangal tradition (fifteenth-eighteenth century) emphasized an ideology of market (hat) ethic where the rights of people (hatuya, literally those engaged with the market), especially of 'lower caste' origin and including women, were upheld against the claims of higher caste men to appropriate goods without paying money. ${ }^{54}$ Treatises like Krittibas Ojha's fifteenth century Bengali rendition of the Ramayana and Kashiram Das's late sixteenth/early seventeenth century Bengali Mahabharata, ${ }^{55}$ the Rajamala genealogical tradition of Tripura, ${ }^{56}$ the eighteenth century writings of Ramprasad, ${ }^{57}$ and Persian as well as Bengali chronicles of the eighteenth and early nineteenth century: ${ }^{5}$ all

${ }^{51}$ Dilipkumar Biswas, Ramamohana-Samiksha (Calcutta: Saraswat Library, 1994).

${ }^{52}$ Roy, "Essay on the Rights of Hindoos over Ancestral Property according to the Law of Bengal,” in English Works, 385-434.

${ }^{53}$ Roy, "Brief Remarks regarding Modern Encroachments on the Ancient Rights of Females, according to the Hindoo Law of Inheritance; Appendix: Letters on the Hindoo Law of Inheritance” (1822), in English Works, 373-84.

${ }^{54}$ The most famous text in the Chandimangal tradition is the late sixteenth and early seventeenth century Mukunda's version: Mukunda, "Akhetik Khanda," in KavikankanaChandi (Calcutta: Dey’s Publishing, 2007), 217-20.

55 Krittibas Ojha, “Ayodhyakanda,” 91-92, 110, "Sundarakanda,” 252-53, “Uttarakanda," 498, in Ramayana (Calcutta: Prabasi Karyalaya, 1926); Kashiram Das, 'Adiparva,' 46, 67, 'Viratparva,' 515-16, 'Mushalaparva,' 1039-64, in Mahabharata (Calcutta: Deb Sahitya Kutir, 1969).

${ }^{56}$ Kaliprasanna Sen, ed., Shrirajamala, 4 vols. (Agartala: Government of Tripura, 2003). Especially vol. 1, 10-19, 53-54, 69-70, vol. 2, 6-8, 38-39, vol. 3, 57, 65. This tradition gives significant powers to people (loka, praja) and to civil and military officers of state to deprive rulers of the throne and install new ones.

${ }^{57}$ Ramprasad, "Vidyasundar," in Ramaprasada-Bharatachandra, 88-89.

${ }^{58}$ Kumkum Chatterjee, The Cultures of History in Early Modern India: Persianization and Mughal Culture in Bengal (Delhi: Oxford University Press, 2009); see also the Bengali treatises Maharaj Krishnachandra Rayasya Charitram (by Rajiblochan Mukhopadhyay) and Rajabali (by Mrityunjay Vidyalankar), both composed in the 1800s; for analyses of these texts, see Milinda Banerjee, "State of Nature, Civilized Society, and Social Contract: Per- 
stressed on property rights, the right to life, and (for women) the right not to be raped as entitlements which rulers could not deprive people (loka, praja) or others (para) of without incurring the danger of being dethroned through (often divinelysanctioned) human action.

Thus, while Rammohun embedded himself in ancient Sanskrit texts to defend the rights of property (for men and women) and life (for women), his discourses need to be situated within an equally relevant genealogy of discourses on rights which was widely prevalent in Bengali literary and oral-performative spheres, at least between the fifteenth and eighteenth century. Rammohun's critique of the Permanent Settlement (which transferred absolutist landlord rights to the zamindars and challenged the customary rights of cultivators) was similarly grounded in invocations of precolonial privileges enjoyed by cultivators, especially the khud-kasht ryots. ${ }^{59}$ Precolonial forms of community self-government (such as embodied in the panchayat system: in the orthography of the period, "punchayet") were cited by Rammohun as models for nineteenth-century governmental reform in India (in evidence given to the authorities in Britain during the discussions preceding the renewal of the English East India Company's Charter in 1833). This, he thought, would allow greater participation to the ruled in the judicial (jury) apparatus. $^{60}$

The same concern for precolonial historicity is present in Rammohun's arguments about the right to religious tolerance and freedom of expression through the press, and indeed of "civil rights and privileges." Rammohun invoked here both Westernmodern constitutionalist-liberal idioms as well as examples drawn from precolonial India. He suggested that the downfall of the Mughal Empire was provoked by Mughal infringement of the "civil and religious rights" of the people, leading to the Sikh and

spectives from Early Modern Bengal on the Origin and Limits of Government,” Calcutta Historical Journal 28, no. 2 (2008): 1-55.

${ }^{59}$ Roy, "Questions and Answers on the Revenue System of India," in English Works, 250.

${ }^{60}$ Ibid., 272-73. 
Maratha rebellions (between the late seventeenth and eighteenth century). ${ }^{61}$ Sikh and Maratha discourses were indeed saturated with ideas about the right to rebellion against 'unjust' rulers, especially if they infringed on the religious and social rights of the people, ${ }^{62}$ and it is interesting (though hardly noticed in existing scholarship) that Rammohun embedded within this topos his own critique of the attempt by the British to curb the freedoms of the press. One may ponder over the connection between Rammohun's positive evaluation of Nanak (the founder of the Sikh movement) as a model monotheist and his celebration of the Sikh fight for liberties. Though not mentioned by Rammohun, there were similar instances of debate about religious liberties in late precolonial Bengal too; for instance in sixteenth and early seventeenth century discussions on the religious rights of Vaishnava city-dwellers or loosely (but not entirely anachronistically perhaps) 'citizens' (nagariya), ${ }^{63}$ and in the mideighteenth century Annadamangal which critiqued Mughal and Nawabi attempts to curb religious rights of 'Hindus. ${ }^{64}$ The very structure of petitioning the ruler for redress of grievances (when customary rights had been trampled) had, apart from British origins, a genealogy in South Asian frameworks of petitioning and protest, such as embodied, for instance, in gohari and arzdasht (a Persian term rendered into Bengali as ardash). ${ }^{65}$

${ }^{61}$ Roy, "Petition against the Press Regulation to the King in Council," in English Works, 445-67.

${ }^{62}$ On the Sikhs, see Louis Fenech, The Darbar of the Sikh Gurus: The Court of God in the World of Men (Delhi: Oxford University Press, 2008); Robert Rinehart, Debating the Dasam Granth (New York: Oxford University Press, 2011); Purnima Dhavan, When Sparrows Became Hawks: The Making of the Sikh Warrior Tradition, 1699-1799 (New York: Oxford University Press, 2011); Hardip Singh Syan, Sikh Militancy in the Seventeenth Century: Religious Violence in Mughal and Early Modern India (London: I. B. Tauris, 2012); Louis Fenech, The Sikh Zafar-Namah of Guru Gobind Singh (New York: Oxford University Press, 2013). On the Marathas, a key text is Kavindra Paramananda, Sivabharata, ed. James W. Laine and S. S. Bahulkar (Delhi: Orient Longman, 2001). See also James W. Laine, Shivaji: Hindu King in Islamic India (New York: Oxford University Press, 2003).

${ }^{63}$ Vrindavana Dasa, Chaitanyabhagavata, ed. Sukumar Sen (Delhi: Sahitya Akademi, 2003), 191-95; Krishnadasa Kaviraja, Chaitanya Charitamrita, ed. Sukumar Sen (Calcutta: Ananda Publishers, 1995), 102-4.

${ }^{64}$ Bharatachandra, “Annadamangal,” in Ramaprasada Bharatachandra, 333-43.

${ }^{65}$ On gohari and ardash, see for example, Mukunda, Kavikankana-Chandi, 149, 218. On arzdashts, see S. Inayat A. Zaidi, introduction to The British Historical Context and Petitioning in Colonial India, by Majid Siddiqi (Delhi: Department of History and Culture, Jamia Millia Islamia, 2005), 9-16; A Descriptive List of the Arzdashts addressed to the Rulers of Jaipur (Rajasthani), 1639-1728 (Bikaner: Rajasthan State Archives, 1978), 30-31, 119-20, 
There is an undercurrent of sectarian triumphalism in some of these discourses as well as in Rammohun's arguments about Hindu toleration as being superior to Mughal Islam or the nexus between Christian missionaries and British state power. ${ }^{66} \mathrm{How}-$ ever in Rammohun (as well as in many of the precolonial Bengali discourses that I have examined), the idiom of rights is expressed not only against Mughal (more broadly, Islamic) power but also in complicity with it. Chaitanyacharitamrita thus emphasized reconciliation between the Islamic qazi and Chaitanya; ${ }^{67}$ in the Annadamangala, Bhavananda received his charter of power (farman) from the Mughal Emperor Jahangir; ${ }^{68}$ in the Maharasht(r)apurana (1751), the gods ultimately switched sides from the Hindu Marathas to the Muslim Nawabs. ${ }^{69}$ In Annadamangal, and even more clearly in Rammohun, the Mughals are not simple foes; they are also givers of power and authority

178-79, 185, 190-91, etc. In the initial period of colonial rule, this older structure of petitioning got inflected with Western structures as petitions were addressed by different categories of Indians, including zamindars, qazis, merchants, weavers, and peasants. For the full text of some of these petitions, see, for instance, Asok Mitra, ed., West Bengal District Records, New Series, Burdwan: Letters Received, 1788-1802 (Calcutta, 1955), 334-35, 488-89; Bhaskar Ghose and Sanat Kumar Bose, eds., Midnapore: Correspondence of the Salt Districts, Hidgellee Salt Division, Letters Received, West Bengal District Records: New Series (West Bengal: Office of the Director of the Census Operations, 1971), 54, 61, 127, 199; Revd. James Long, Selections from unpublished records of government for the years 1748-1767 inclusive relating mainly to the social condition of Bengal, with a map of Calcutta in 1784 (Calcutta: Office of Superintendent of Government Printing, 1869), 347, 430. However there were also crucial differences as the British often showed little patience with subaltern protests that took a violent/militant turn. Thus, Henry Strachey, the District Judge of Midnapore (in Bengal) confessed in 1802: "Formerly in these Provinces (and it is still the case throughout the East) the cultivators of the soil, when oppressed beyond endurance, were accustomed to assemble in a crowd with ploughs and other implements and demand justice with violent and outrageous clamour. They still sometimes resort to this practice, though with us it can avail them nothing ... " Strachey further noted that the ryots now had no effectual redress against the abuse of powers entrusted to the zamindars because of the expenses and delay of prosecution in the courts. See Notes on the Early Judicial Administration of the District of Midnapore, based on the volumes of correspondence in the Judges' Office extending from 1789 to 1829 (Calcutta, 1904), 7-8, 11.

${ }^{66}$ For example, Roy, "The Brahmunical Magazine or the Missionary and the Brahmun, being a Vindication of the Hindoo Religion against the Attacks of Christian Missionaries,” in English Works, 145-47.

${ }^{67}$ Krishnadasa Kaviraja, Chaitanya Charitamrita, 103-4.

${ }^{68}$ Bharatachandra, “Annadamangal,” in Ramaprasada Bharatachandra, 343.

${ }^{69}$ Gangaram, Maharashta Purana (Honolulu: The Association for Asian Studies, 1965). 
to the 'Hindus.' Thus Rammohun, in an appeal to the British King in Council, celebrated the Mughals for having allowed Indians to the highest offices of state as governors of provinces and commanders of armies, as advisers to the ruler "without disqualification or degrading distinction on account of their religion or the place of their birth." The Mughals were praised for giving large grants of land (including revenue-free grants) and salaries to Indians. ${ }^{70} \mathrm{~A}$ precolonially-embedded model of distributed and participatory power thus came in handy to critique modern British forms of racial exclusion which prevented Indians from achieving high state power. And finally, Rammohun invoked forms of free mobility of travel in "Asia" to urge to the French Foreign Minister that Europeans should also remove restrictions on travel between countries since "all mankind are one great family of which numerous nations and tribes now existing are only various branches." ${ }^{71}$

\section{THE FORGOTTEN SELVES AND FORGOTTEN RIGHTS}

So far the narrative has remained rather optimistic: Rammohun appears to have articulated a comparativist 'world-historically' embedded vision of reform drawing on multiple Indic, Islamic, and European concepts of selfhood and rights. Yet, from another perspective, Rammohun seems remarkably retrogressive. His discourse on women's rights was embedded in Sanskritic texts and colonial ideologies of legal reform, and completely ignored the more liberal customary practices prevalent among nonBrahmanical groups in his period, among peasant, pastoral, and forest- or fishing-oriented communities, for example. Among these communities, practices of widow remarriage, divorce, adult marriage, and bride price (rather than dowry) were often far more common; women had often greater sexual freedoms

${ }^{70}$ Roy, "Petition against the Press Regulation to the King in Council," in English Works, 462.

${ }^{71}$ For the correspondence (December 1831 to January 1832) relating to Rammohun's visit to France, see Roy, Ramamohana, 484-88 (quote from 486). 
than among Brahmanical communities. ${ }^{72}$ Rammohun generally ignored these alternate models of freedom. But since these models left their imprint on religious mores and legends, Rammohun could not altogether keep them out of his horizon; he wrote disparagingly about legends and practices (of Vaishnava, Shaiva, and Shakta-Tantric origin) which were grounded in free sexual association between men and women, in 'indecent' songs and dance, or which articulated what Rammohun construed as deviant sexual behavior (including transgender love and crossdressing). Non-Brahmanical aspirations for social mobility were often articulated through legends, for instance about the god Shiva dallying with (peasant) Koch women or of the god Krishna being associated with cattle-rearing communities and especially their women (gopis). Rammohun offered severe critiques of myths which associated divinity with people of such nonBrahmanical origin. ${ }^{73}$ His critique of female deities (such as various forms of the mother goddess or of Radha, Krishna's beloved) also demonstrated a masculinization of theology. Given that precolonial Indian women, for example in Bengal, sometimes articulated their models of autonomy and rulership by associating themselves with female deities ${ }^{74}$ the marginalization of female deities also reflected a certain marginalization of the possibility of female agency.

${ }^{72}$ For summary overviews, see, for example, Rachel Sturman, "Marriage and Family in Colonial Hindu Law," in Hinduism and Law: An Introduction, ed. Timothy Lubin, Donald R. Davis Jr., and Jayanth K. Krishnan (Cambridge: Cambridge University Press, 2011), 89104; Lucy Carroll, "Law, Custom, and Statutory Social Reform: The Hindu Widows' Remarriage Act of 1856,” The Indian Economic and Social History Review 20, no. 4 (1983): 36388.

73 For example, Rammohun Roy, "Gosvamir sahita Vichara," 160, and "Pathya Pradana,” 297-99, in Ramamohana; Rammohun Roy, “A Defence of Hindoo Theism,” 97, 99, in English Works.

${ }^{74}$ In the late precolonial Rajamala tradition of Tripura for example, queens (between the thirteenth and sixteenth century) who were engaged in welfare-oriented politics, military leadership, public works, and charity were compared to the goddesses Parvati-Durga and Lakshmi, or simply sanctified as great goddesses (mahadevi); see Shrirajamala, 1:55-57; 2:9, 39, 67-68. In Bishnupur, queens asserted their rulership by comparing themselves to Radha, as visible in inscriptions analysed in Samuel Wright, "From Prasasti to Political Culture: The Nadia Raj and Malla Dynasty in Seventeenth-Century Bengal,” The Journal of Asian Studies 73, no. 2 (2014): 397-418. 
While Rammohun sought to combat varna-jati and genderoriented social stratification, it would be simplistic to construe the conflict between him and his Indian opponents as a war between liberals and conservatives. I do not think that it has ever been observed to what extent Rammohun actually shared a common ground with his opponents. His Indian opponents did not dispute the universality of salvation. Mrityunjay Vidyalankar (ca. 1762-1819), the famous Brahmin associated with the College of Fort William and with the Supreme Court in Bengal, for example suggested that Muslims and Christians worshipped divinity in their own way, in mosques and churches. ${ }^{75}$ While Rammohun embedded his ideas of the global rights-bearing self in every atman having the potential to access brahman, his opponents suggested that anyone, including the Chandals (ritually one of the lowest groups in the varna-jati hierarchy) and Shudras and antyajas (lower castes) in general, if they worshipped Vishnu or Shiva, would be considered high in status, would sanctify everyone, and could sit together and have meals with Brahmins or teach everyone. In support they cited precolonial purana texts like Brahmavaivartapurana, Skandapurana, and Padmapurana. ${ }^{76}$

This was not empty rhetoric: throughout late precolonial Bengal (and indeed across India, as noted before), devotional forms of religion had been used by agrarian and artisanalmercantile communities to claim social honor and power. The worship of 'idols' in temples which was condemned by Rammohun was one of the principal conduits for social mobility in sixteenth to eighteenth century Bengal for non-Brahmin communities. ${ }^{77}$ Rammohun, in dismissing these claims, effectively dismissed alternate sources of rights-bearing 'global' selfhood. Vaishnava, Shaiva, or Shakta-Tantric forms of devotion were criticized by Rammohun for giving high honor to everyone who embraced their particular god. Rammohun cited, apart from the

${ }^{75}$ Mrityunjay Vidyalankar, "Vedantachandrika” (1817), in Roy, Ramamohana, 62829. Roberton, Rammohan, however suggests that the famous Bengali notable Radhakanta Deb was the real author of the piece (33-37, 51-53, 148-49). If this is so, this would be quite interesting since Radhakanta was a Kayastha and therefore, in strict Brahmin eyes, a Shudra who notionally did not have the right to indulge in such discourses.

76 'Dharmasamsthapanakamkshi,' “Pashandapidana” (1823), in Roy, Ramamohana, 650; Utsavananda Vidyavagisha, in Roy, Ramamohana, 695.

${ }^{77}$ Hitesranjan Sanyal, Social Mobility in Bengal (Calcutta: Papyrus, 1981). 
puranas, Shakta and Shaiva texts such as Kulavali Tantra, Mahanirvana Tantra, and Kularnava, which gave high status to all devotees, including Chandals and mlechchhas (loosely, foreigners), equating them with divinity. Rammohun condescendingly argued that going by this logic all Shudras and antyajas were therefore holy since they followed one devotional tradition or another; his opinion was that such widespread distribution of holiness was absurd. The by-product of this attitude was to dismiss communitarian-collective forms of self-assertion that articulated a sense of equality among all selves under the banner of a particular deity who was equated with the supreme divinity. ${ }^{78}$ Rammohun's privileging of the Vedas (to which Shudras and women had no access) over sectarian Vaishnava, Shaiva, and Shakta-Tantric texts which claimed a Vedic status (but were open to people of any origin) had a similar hierarchical ramification; Rammohun condemned these positions as characterizing 'new' (navina) discourses. ${ }^{79}$ While Rammohun's opponents probably did not come from 'low caste' communities (unless we allow for a Shudra author of the Vedantachandrika), their discourses do bear the mark of the pressure exerted by lower castes and women on devotional movements of the time. Rammohun thus opposed, in effect, these subaltern-inflected interpretations of the globality of salvation and social honor.

In practical political-economic terms, Rammohun's pacific advocacy of greater rights for peasants (as discussed above) to be given under British guidance can be regarded as utopian at best and hypocritical at worst. Rammohun showed little sympathy for peasant revolts, often organized through devotional Indic and Islamic grammars of justice, which animated late eighteenth and early nineteenth century Bengal. ${ }^{80}$ His celebration of the earlier precolonial Sikh and Maratha revolts (with their strong devo-

\footnotetext{
${ }^{78}$ Rammohun Roy, “Pathya Pradana,” in Ramamohana, 271-72.

${ }^{79}$ For example, Rammohun Roy, “Gosvamir sahita Vichara,” in Ramamohana, 15760.

${ }^{80}$ On the political theology of these revolts, see, for example, Gautam Bhadra, Iman o Nishan: Unish Shataker Banglar Krishak Chaitanyer ek Adhyay, c. 1800-1850 (Calcutta: Subarnarekha, 1994).
} 
tional underpinnings) makes this silence about the anti-British revolts all the more baffling. Rammohun's support for European colonization of India to promote the economic and cultural development of the country also shows the limitations of a model of global unity and mobility of free trade capital that remained reticent about imperial forms of oppression. ${ }^{81}$ Rammohun's vision of a 'global' rights-bearing self, while not a pure function of colonial capitalism or Indian elitism, certainly had peculiar blind spots: it ignored or sometimes actively condemned alternate forms of universality and different ideas of social privileges and rights which were animating anti-colonial and anti-hierarchical social mobility movements during his lifetime and offering diverse critiques of South Asian forms of social exploitation as well as European racial-economic domination.

\section{CONCLUSION: SUPPRESSED GENEALOGIES OF THE GLOBAL}

The 'global,' or from another perspective 'international,' turn in intellectual history has become a visible feature in existing scholarship. ${ }^{82}$ This essay, through a case study of Rammohun Roy in the context of South Asia, has sought to grapple with the implications of this turn in the study of intellectual history. I have suggested that the choice of what constitutes 'global,' and therefore a fit subject matter of some form of global intellectual history, is dependent at least partly on the historian's own choices and biases: the 'global' as a historiographic category is fashioned as much by the 'global historian' as by any historical phenomena. Rammohun helps us in two ways in pursuing this line of enquiry.

Firstly, his example clearly shows that categories of globality did not emanate in early nineteenth century India from the modalities of European intervention alone. Shruti Kapila has recently suggested that ideas are not currencies, and circulation

${ }^{81}$ Rammohun Roy, "Remarks on Settlement in India by Europeans," (1832) in English Works, 313-20.

${ }^{82}$ On the "international” turn, see David Armitage, "The International Turn in Intellectual History,” in Rethinking Modern European Intellectual History, ed. Darrin M. McMahon and Samuel Moyn (New York: Oxford University Press, 2014), 232-52. 
offers an inadequate methodology for understanding the production of the global. ${ }^{83}$ Rammohun's dense protocols of intertextual citation (through diachronic conversation and contestation, rather than simple synchronic circulation) allow us to trace the precolonial South Asian categories through which he (as well as his Indian opponents) arrived at notions of the global. At the most abstract level, references to the global were present in precolonial South Asia through such terms as vishva, jagat, sarva, and sarvabhuta; in an age before any conceptions of the nationstate, definitions of the global constituted a relevant unit of reference for advancing any philosophical-epistemological claim. The correlate of this global horizon of reference was the atman, the self. The quest for liberation (mukti) and salvation (moksha) of this self was not only a soteriological concern; as I have demonstrated, it also had very pertinent this-worldly implications. Precolonial South Asian societies, like other societies in other times and places, were arranged along stratified hierarchies: in South Asia, varna-jati and gender stratification were important ordering categories. In some discourses therefore, these stratified categories obscured the presence of the global; liberation/salvation as well as this-worldly authority were made the exclusive prerogative of some beings (for example, Brahmin or $d v i j a /$ twice-born males). In other discourses, the category of global selfhood was emphasized through the repetitive suggestion that all selves potentially had equal right (adhikara) of access to the universal self (brahman); techniques were suggested (including devotion and knowledge of purana, itihasa, and agama texts) through which everyone could achieve liberation and, inter alia, achieve the highest social honor in the present world, including the right to sit together and have meals with or instruct Brahmin men. Here the category of the global included women, the lower castes (Shudra and antyaja) and the foreigner (mlechchha). At a more mundane level, categories such as people (loka), the ruled (praja, literally 'offspring'), or the other ( $p a-$

${ }^{83}$ Shruti Kapila, “Global Intellectual History and the Indian Political,” in Ibid., ed. McMahon and Moyn, 259-60. 
ra) articulated notions of selfhood which possessed certain rights (to life, property, freedom from sexual violation, religious tolerance). The discourse on rights was frequently articulated in precolonial Bengal through a discourse on the limits of what rulers could do and the punishments they would incur if they violated these rights. These categories and other ones such as notions of the city-dweller (nagariya) and market-person (hatuya) cut across lines of varna-jati and gender.

Produced through agonistic relations as well as complicity with Indic and Indo-Islamic social and political hierarchies, these discourses helped Rammohun to articulate his own vision of the global rights-bearing self. Confronted with the colonial state, Rammohun could adopt Western-modern notions of 'rights' as well as precolonial Indic and Indo-Islamic models of entitlements, hybridizing them to articulate universalistic ideas of rights to life, property, civil and religious liberties, and participation in government. Positioned at a frontier of the British Empire, his very position of colonial marginality, as well as the deep prehistory of discourses on rights-bearing selfhood and shared authority of which his Indo-Islamic society was the heir, allowed Rammohun to produce a deracialized notion of liberty and global governance. Fighting against a racial state which suppressed different liberties of Indians, and fearing a confessionalized nexus between state power and Christian missionaries, Rammohun was able to produce a deracialized, non-sectarian, de-territorialized notion of global governance that could simultaneously attack Indian social hierarchies and British-colonial racial exclusion. In this sense, the 'global' was a product of the margins of empire, not a simple gift of the Europeans to the extra-European world. The example of Rammohun shows that a global intellectual history needs to be sensitive to the categories of globality and selfhood produced by multiple societies in the world. We would have a very impoverished historiography if we lost sight of these various conceptual and practical origination points of globality.

Secondly, Rammohun alerts us to the problems besetting any "global intellectual history" when one enforces one paradigm of globality to the exclusion of others. Taking a cue from Sanjay 
Subrahmanyam, and sifting through categories such as prachina/navina or prachina/adhunika and ancient/modern which Rammohun used, I have argued that Rammohun was in a sense a kind of world historian whose epistemology was fashioned by a nuanced perception of chronological as well as spatial diversity and difference. While far less racialized than Hegel's Weltgeschichte, Rammohun's sense of world history nevertheless shares something with Hegel: a predilection for monocausality. If the Geist offered to Hegel a way of ordering the world into inferior and superior civilizations, for Rammohun it was the knowledge of monotheism which made some people more global and superior to others who lacked such beliefs. It was this spirit of condescension that made Rammohun unable to sympathize with those of his compatriots who subscribed to different kinds of religious beliefs, sexual mores, or community organization. This hierarchical strain also led Rammohun to regard British rule as something which would improve the moral and economic conditions of Indians; it made him insensitive to the different peasant revolts or lower caste social movements which animated Bengal in the late eighteenth and early nineteenth century. Such a perspective also rendered him incapable of appreciating the gender norms present among non-Brahmanical communities of his time; his condemnation of what he regarded as plebeian sexualities was unequivocal. While Rammohun may have challenged many South Asian and British imperial forms of exploitation, his inability to be sufficiently open to other horizons implied that he became complicit with the constitution of a kind of deterritorialized form of administration which bears remarkable similarities with Hardt and Negri's concept of 'empire': a set of rules functional all across the world, in no intrinsic need of a racial or territorial prop, but operating through a semi-coercive semivoluntaristic regime of stratified social and labor relations which is universally present and globally applicable. ${ }^{84}$ As a colonized subject yearning for deracialization, it was in fact far more plau-

${ }^{84}$ Michael Hardt and Antonio Negri, Empire (Cambridge, Mass.: Harvard University Press, 2000). 
sible for Rammohun to pioneer a Hardt and Negri format of global governance than it was for British administrators who had race and territorial empire as bastions of administrative control. In any case, the terms in South Asian languages and in English which Rammohun deployed to enunciate his vision show a remarkable semantic flexibility, conflating the universal and the global. The "universe" and the "world" can alike be found in his English works, while the Sanskrit/Bengali terms that he used defy monochromatic translation. Rammohun demonstrates acutely the metaphysical and teleological assumptions which often structure visions of the 'global'; even when he practices comparativist historical-sociological studies of different societies, his ideological predilections overdetermine the narrative he constructs.

There is a risk that the modern intellectual historian, much like Rammohun, may also privilege one kind of globality when ordering his categories; where Rammohun had privileged a particular interpretation of monotheism, today's historians may substitute that with other more 'secular' narratives (which nevertheless can have crypto-theological implications, as pointed out recently, for example, by Robert Yelle ${ }^{85}$ ), including that of giving primacy to the exclusively 'Western' origination of concepts of rights and liberties (the 'West' here being, needless to say, a constructed category of legitimation). In an important essay Subrahmanyam writes that "one is constantly at risk of reproducing that old and familiar history of the 'global,' where it all begins in the Mediterranean, passes to the Atlantic, and eventually expands by means of concentric circles to the rest of the world. This was precisely the rooted, and eventually successful, objection that historians of Asia raised to the Wallersteinian perspective: that it was very old Eurocentric wine in a shiny new plastic bottle labeled "world-systems theory." 86 I would add to this that the risk of reproducing old Eurocentric wine in new global bottles is far more than an academic and anodyne one. The moment we lose sight of multiple understandings of globali-

${ }^{85}$ Robert A. Yelle, The Language of Disenchantment: Protestant Literalism and Colonial Discourse in British India (New York: Oxford University Press, 2013).

${ }^{86}$ Sanjay Subrahmanyam, "Historicizing the Global, or Labouring for Invention?" History Workshop Journal 64, no. 1 (2007): 331. 
ty, we also run the risk of forgetting (and thereby becoming complicit with the suppression of) notions of global selfhood and ideas of rights or justice which are produced by people in different societies, invoking different older and newer sets of discourses. In case of Rammohun we can only resort to 'subjunctive histories' (with a nod to Alan Bennett's play The History Boys), asking what different shape history might have taken in India if more people in positions of power were sensitive to the alternate forms of global selfhood and rights which were thrown up in South Asia through the involvement of non-Brahmanical subalternized communities and women.

'Global intellectual history' may involve itself with critiques of all forms of ideologically-embedded social exclusion, whether produced by colonial and neocolonial forms of domination, or by more regionalized (including extra-European and precolonialorigin) forms of hierarchy. Different formats of social dominance today are embedded in the overt or secret complicity between translocal and local technologies of power: a simultaneous critique is needed of these multiple origination points of bondage. The category of the 'global' in 'global intellectual history' can provoke the historian to explore these multi-nodal intersections through which different forms and concepts of injustice as well as justice are produced, foregrounding localized vocabularies as well as transborder movements in constructing (for example) idioms of struggle against patriarchal, class, or communitarian forms of exploitation.

I would conclude by suggesting that the role of anyone trying to practice 'global intellectual history' today bears an ethical dimension: he or she has the responsibility of studying "competing universalisms" (David Armitage) ${ }^{87}$ and multiple conceptions of globalities, so that from all the fragmented subjectivities which are constructed through these contestations, a more inclusive future can be built up. The avoidance of mono-origin, mono-causal, mono-dimensional, interpretations of globality

\footnotetext{
${ }^{87}$ Armitage, “International Turn,” 240.
} 
and global history is a first move in that direction. The volume Global Intellectual History has taken a significant step towards challenging mono-origin narratives of the global in the domain of intellectual history; indeed running throughout the volume is a pervasive anxiety about the inadequacies of the 'truncated universalism' model. The editors and contributors to the volume have foregrounded the urgent necessity for conceptualizing more nuanced ways of interpreting the 'global,' offering empirically-situated case studies to ground their methodological points.

It can be hoped that future historians will heed some of the warnings and also be instructed by the plural voices and methodologies offered in it. One of the greatest appeals of 'global intellectual history' may lie today in bringing out the meetingpoints between multiple ways of imagining transborder selfhood. Such academic focus need not include only geographically expansive regimes which span the world, but also oneiric horizons fantasized about by various subalternized individuals and groups. Subalternized selves have perforce a narrower radius of presence than powerful empires, but marginalized globalities promise to offer as interesting lessons about globality as accounts of imperial modernities. The 'global intellectual historian' may identify the many specific points and crossroads at which different actors have sought to produce universalizable understandings of selfhood, rights, and justice; scholarship can only be enriched by such a polyglot focus. 